\title{
Inactivation of glucocorticoids by $11 \beta$-hydroxysteroid dehydrogenase enzymes increases during the meiotic maturation of porcine oocytes
}

\author{
Rachel J Webb, Neera Sunak ${ }^{1}$, Lisa Wren and Anthony E Michael \\ Division of Clinical Developmental Sciences, Academic Section of Obstetrics and Gynaecology, Centre for \\ Developmental and Endocrine Signalling, St George's University of London, Level 3 Lanesborough Wing, Cranmer \\ Terrace, London SW17 ORE, UK and ${ }^{1}$ Department of Biochemistry and Molecular Biology, University College London, \\ Gower Street, London WC1E 6BT, UK \\ Correspondence should be addressed to R Webb; Email: r.webb@sgul.ac.uk
}

\begin{abstract}
Recent reports have shown that glucocorticoids can modulate oocyte maturation in both teleost fish and mammals. Within potential target cells, the actions of physiological glucocorticoids are modulated by 11 $\beta$-hydroxysteroid dehydrogenase (HSD11B) isoenzymes that catalyse the interconversion of cortisol and cortisone. Hence, the objective of this study was to establish whether HSD11B enzymes mediate cortisol-cortisone metabolism in porcine oocytes and, if so, whether the rate of glucocorticoid metabolism changes during oocyte maturation. Enzyme activities were measured in cumulus-oocyte complexes (COCs) and denuded oocytes (DOs) using radiometric conversion assays. While COCs and DOs oxidised cortisol to inert cortisone, there was no detectable regeneration of cortisol from cortisone. The rate of cortisol oxidation was higher in expanded COCs than in compact COCs containing germinal vesicle (GV) stage oocytes (111 \pm 6 vs $2041 \pm 115$ fmol cortisone/oocyte.24 $\mathrm{h} ; P<0.001)$. Likewise, HSD11B activities were $17 \pm 1$ fold higher in DOs from expanded COCs than in those from compact COCs $(P<0.001)$. When $\mathrm{GV}$ stage oocytes were subject to a $48 \mathrm{~h}$ in vitro maturation protocol, the enzyme activities were significantly increased from $146 \pm 18$ to $1857 \pm 276 \mathrm{fmol}$ cortisone/oocyte.24 h in GV versus MII stage oocytes respectively $(\boldsymbol{P}<\mathbf{0 . 0 0 1})$. Cortisol metabolism was inhibited by established pharmacological inhibitors of HSD11B (glycyrrhetinic acid and carbenoxolone), and by porcine follicular and ovarian cyst fluid. We conclude that an HSD11B enzyme (or enzymes) functions within porcine oocytes to oxidise cortisol, and that this enzymatic inactivation of cortisol increases during oocyte maturation.
\end{abstract}

Reproduction (2008) 136 725-732

\section{Introduction}

The production of an oocyte competent of fertilisation and normal embryonic development is controlled by a series of highly organised signals and intracellular events, many of which are not fully understood. Recent experiments have shown physiological glucocorticoids can exert direct actions on the oocyte and affect its meiotic competence. In several different teleost fish species, cortisol and related hydroxylated metabolites of progesterone have been shown to induce oocyte maturation (Kime et al. 1992, Petrino et al. 1993, Mugnier et al. 1997, Pinter \& Thomas 1999, Milla et al. 2006). In contrast, in the two species of mammals investigated to date (mouse and pig), glucocorticoids appear to exert a negative effect on oocyte maturation (Yang et al. 1999, Andersen 2003). Incubation of mouse oocytes with the synthetic glucocorticoid dexamethasone (DEX) did not prevent germinal vesicle breakdown (GVBD) but decreased the proportion of oocytes progressing to the metaphase II (MII) stage of development (Andersen 2003). Exposure of porcine oocytes to both cortisol and DEX suppressed both GVBD and progression of oocytes to MII, and this effect could be prevented using the glucocorticoid receptor (GR) antagonist RU486 (Yang et al. 1999). A subsequent study by the same group found that DEX decreased expression of cyclin B1. Since cyclin B1, along with P34cdc2, is a key component of the 'maturation promoting factor' (MPF) complex, the adverse effect of cortisol and DEX on maturation of porcine oocytes was attributed to the suppression of cyclin B1 (and hence MPF) levels (Chen et al. 2000).

Within a wide range of potential target tissues, including ovarian follicles, the cellular actions of glucocorticoids are modulated by $11 \beta$-hydroxysteroid dehydrogenase (HSD11B) enzymes that mediate the conversion of cortisol to its inert 11-ketosteroid metabolite, cortisone (reviewed by White et al. 1997, Kotelevtsev et al. 1999, Seckl \& Walker 2001, Tomlinson et al. 2004, 
Draper \& Stewart 2005). To date, two biochemically distinct HSD11B enzymes have been cloned. While type 1 HSD11B (HSD11B1) is a relatively low affinity, $\operatorname{NADP}(\mathrm{H})$-dependent bidirectional enzyme that can either inactivate cortisol or regenerate this physiological glucocorticoid from inert cortisone, HSD11B2 is a high affinity $\mathrm{NAD}^{+}$-dependent enzyme that acts exclusively as a dehydrogenase to inactivate cortisol (White et al. 1997, Kotelevtsev et al. 1999, Seckl \& Walker 2001, Tomlinson et al. 2004, Draper \& Stewart 2005). Previously, the balance of cortisol-cortisone metabolism by HSD11B enzymes in human ovarian follicles has been linked to the ability of human oocytes to undergo fertilisation in vitro and to give rise to viable embryos in women undergoing assisted conception (Michael et al. 1993, 1995, 1999, Keay et al. 2002, Lewicka et al. 2003, Thurston et al. 2003a). Recently, we have reported that both cloned HSD11B isoenzymes are co-expressed in the mural granulosa cells of bovine and porcine antral follicles, and have shown that in both cows and pigs, the ability of the HSD11B enzymes to inactivate cortisol within the mural granulosa cells increases during antral follicle growth (Sunak et al. 2007, Thurston et al. 2007).

Human, bovine and porcine antral follicles and spontaneous ovarian cysts have each been found to contain hydrophobic lipids that can selectively inhibit cortisol metabolism by the $\mathrm{NADP}(\mathrm{H})$-dependent HSD11B1 enzyme without affecting the $\mathrm{NAD}^{+}$-dependent oxidation of cortisol by HSD11B2 (Thurston et al. 2002, 2003 b, Sunak et al. 2007). Our most recent studies have established that in porcine antral follicles, the progressive increase in glucocorticoid inactivation with follicle growth coincides with a progressive decline in the levels of the lipid inhibitors of HSD11B1 in the follicular fluid (FF), whereas the highest level of the HSD11B1 inhibitors occur in ovarian cyst fluid (CF) accompanied by very low levels of glucocorticoid metabolism in granulosa cells from these cystic follicles (Sunak et al. 2007).

In terms of modulating glucocorticoid actions within the oocyte itself, Benediktsson et al. (1992) were the first to document the expression of high levels of HSD11B1 mRNA and protein in preovulatory rat oocytes. Subsequent studies confirmed the expression of HSD11B1 in human GV stage and MII oocytes with no detectable expression of HSD11B2 mRNA or protein in preovulatory or MII oocytes (Ricketts et al. 1998, Smith et al. 2000). However, no studies to date have established whether HSD11B enzymes are functional in mammalian oocytes and, if so, whether they catalyse net inactivation or regeneration of cortisol. Given the apparent adverse effects of glucocorticoids on the maturation of porcine oocytes, the primary aim of this study was to establish whether glucocorticoids are metabolised by HSD11B enzyme in porcine cumulus-oocyte complexes (COCs) and in denuded porcine oocytes and, if so, whether levels of glucocorticoid metabolism change between the GV and MII stages of oocyte maturation. A secondary aim was to establish whether cortisol-cortisone metabolism in COCs and/or denuded oocytes (DOs) could be modulated by the lipid inhibitors of HSD11B1 activity in porcine FF and ovarian CF.

\section{Results \\ GV stage oocytes exhibit HSD11B activity}

Initial experiments were performed to determine whether either compact COCs or the DOs from these complexes had any HSD11B activity. Both COCs and denuded GV stage oocytes were capable of oxidising $\left[{ }^{3} \mathrm{H}\right]$-cortisol to $\left[{ }^{3} \mathrm{H}\right]$-cortisone (Fig. 1a), but did not exhibit detectable reduction of $\left[{ }^{3} \mathrm{H}\right]$-cortisone to $\left[{ }^{3} \mathrm{H}\right]$-cortisol. Although they did not differ significantly, $11 \beta$-dehydrogenase activities were consistently higher in COCs $(111 \pm 6, n=10)$ than in the DOs $(88 \pm 7, n=8)$ within each assay, suggesting that both the cumulus cells and the oocyte may be capable of inactivating cortisol. Both carbenoxolone (CBX) and glycyrrhetinic acid (GA), these being established inhibitors of both cloned HSD11B enzymes (Armanini et al. 1982, Stewart et al. 1990, Kageyama et al. 1992, Latif et al. 1992, Marandici \& Monder 1993, Ulick et al. 1993), were able to suppress the net oxidation of cortisol by up to $81 \%$ in both compact COCs and GV stage oocytes $(P<0.01$; Fig. 1a).

\section{HSD11B activity increases during oocyte maturation}

Having established the presence of an active HSD11B enzyme system in porcine oocytes at the GV stage, we investigated the balance of cortisol-cortisone metabolism in maturing porcine oocytes that had undergone GVBD. Initially, we studied oocytes obtained from abattoir tissue where the oocytes were assessed as having resumed meiosis in vivo as reflected by expansion of the cumulus mass. Both expanded COCs and DOs isolated from expanded COCs were able to oxidise cortisol to cortisone (Fig. 1b). As with the compact COCs/DOs, cortisol metabolism by the expanded COCs/DOs could be inhibited by both CBX and GA, by $84 \pm 1 \%(n=4)$ and $92 \pm 1 \%$ respectively $(n=4 ; P<0.01$; Fig. $1 \mathrm{~b})$.

Rates of cortisol oxidation in expanded COCs and DOs were consistently 20-fold higher than in the compact COCs and GV stage DOs, suggesting an increase in activity as the oocyte matures. However, to test this hypothesis directly, we performed assessments of enzyme activities in oocytes that had been stimulated to mature through to the MII stage in vitro. Oocytes from COC's were found to have diffuse chromatin and 
(a)
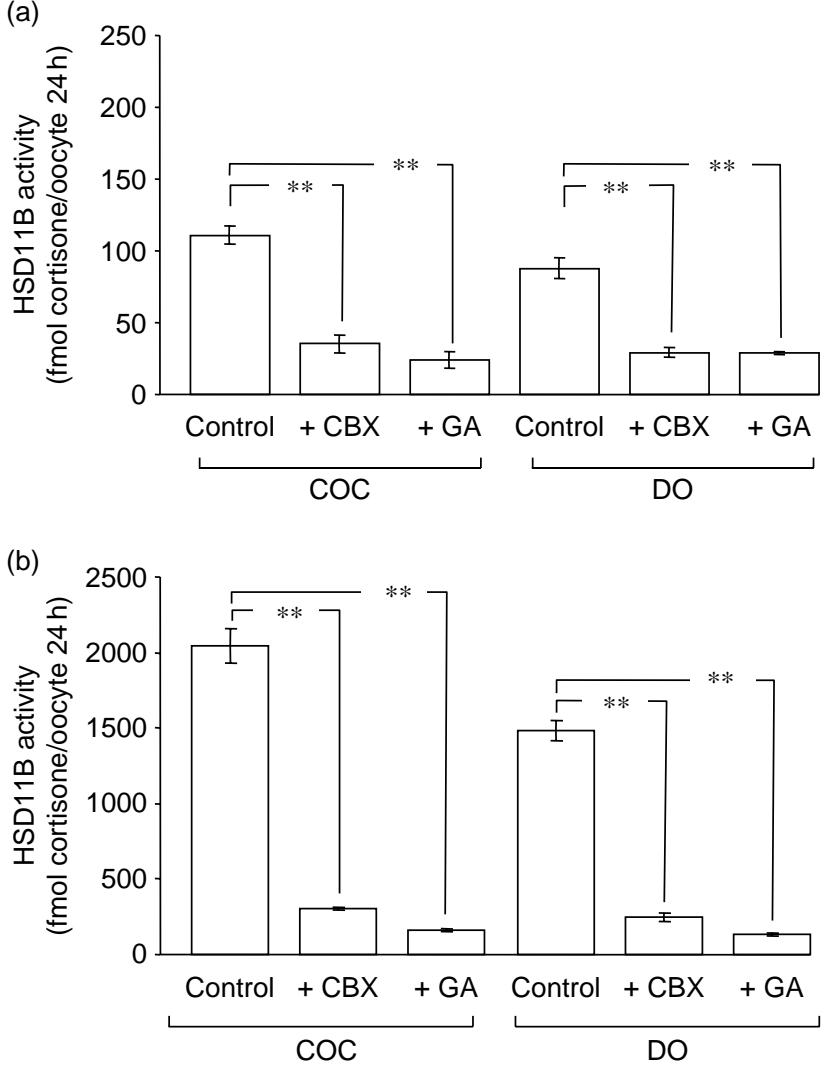

Figure 1 Net oxidation of cortisol by HSD11B increases during oocyte maturation in cumulus-enclosed and denuded porcine oocytes. Enzyme activities were assessed by incubating (a) COCs and denuded oocytes from compact COCs and (b) COCs and denuded oocytes from expanded COCs with $100 \mathrm{nmol} / /\left[{ }^{3} \mathrm{H}\right]$-cortisol in the presence of medium alone (control), carbenoxolone (+CBX; $10 \mu \mathrm{mol} / \mathrm{l})$ or glycyrrhetinic acid ( $+\mathrm{GA} ; 10 \mu \mathrm{mol} / \mathrm{l})$. All data are the mean \pm s.E.M. values for five groups of COC/DOs. ${ }^{* *} P<0.01$ versus COCs/DOs incubated in the absence of $\mathrm{CBX}$ or GA.

no meiotic spindle, confirming they were either in the GV stage or just commencing GVBD (Fig. 2a and b). By contrast, in vitro maturation (IVM) oocytes that had extruded a polar body (PB) had progressed to the MII stage as verified by the alignment of their chromosomes on a metaphase plate with a clear meiotic spindle (Fig. 2c and d). On this basis, presence of a PB was used as an indicator of progression to MII in living (non-fixed) oocytes that could then be used in the radiometric conversion assay for HSD11B enzyme activity.

In six independent experiments, net rates of cortisol oxidation were consistently and significantly higher in denuded IVM oocytes that had reached MII than in denuded GV stage oocytes ( $P<0.001$; Fig. 3). Moreover, the rates of enzymatic inactivation of cortisol in IVM MII oocytes $(1857 \pm 276 \mathrm{fmol}$ cortisone/oocyte. $24 \mathrm{~h}$ ) were consistent with the absolute enzyme activities measured in DOs from in vivo expanded COCs $(1485 \pm 65 \mathrm{fmol}$ cortisone/oocyte. $24 \mathrm{~h}$ ).
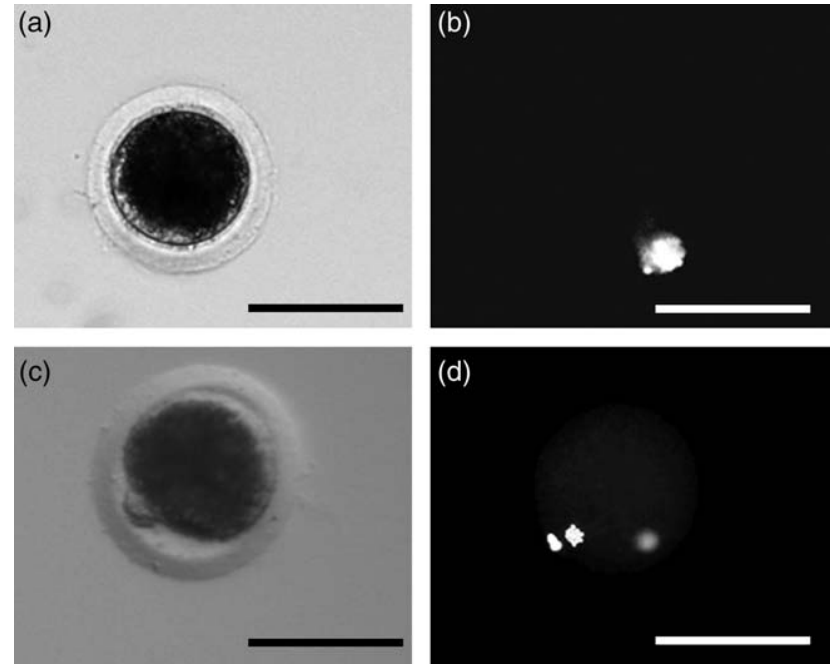

Figure 2 Confirmation of the nuclear maturation status of GV stage oocytes from compact COCs and in vitro matured (IVM) oocytes. ( $a$ and b) Porcine oocytes isolated from compact COCs and (c and d) oocytes generated by IVM that had extruded a polar body were confirmed to be in the GV and in MII stage by fixing and staining with PI (b and d respectively) and an FITC-labelled anti-tubulin antibody (not shown). Bar $=100 \mu \mathrm{m}$.

\section{Porcine FF and CF inhibit HSD11B activity in COCs and DOs}

To determine whether compounds present in FF from large antral follicles and CF could affect the HSD11B enzyme activities in porcine oocytes, cortisol metabolism was assayed in compact and expanded COCs and DOs, each incubated in the presence of medium alone (control), with $10 \%(\mathrm{v} / \mathrm{v})$ large antral FF or with $10 \%(\mathrm{v} / \mathrm{v})$ $\mathrm{CF}$ from spontaneous ovarian cysts. FF had no significant effect on cortisol metabolism in compact COCs and their enclosed immature oocytes, but inhibited HSD11B activity by $42 \pm 6 \%$ and $36 \pm 8 \%$ in expanded COCs and DOs from those expanded COCs respectively $(P<0.001$; Fig. 4). Although the inhibitory effect of $\mathrm{CF}$ on cortisol metabolism in compact COCs $(41 \pm 18 \%$ inhibition) did not achieve statistical significance (Fig. 4a), CF significantly inhibited $11 \beta$-dehydrogenase activities by between $47 \pm 5 \%$ and $62 \pm 9 \%$ in expanded COCs and in DOs from both compact and expanded COCs $(P<0.001$ in each case; Fig. 4$)$.

\section{Discussion}

The physiological glucocorticoid cortisol is present throughout the development of porcine antral follicles at concentrations ranging from 115 to $144 \mathrm{nmol} / \mathrm{I}$ (Sunak 2007), which are sufficient to bind and activate intracellular GRs. Although several studies have reported the expression of HSD11B1 mRNA and protein in the mammalian oocyte and surrounding cumulus granulosa cells (Benediktsson et al. 1992, Ricketts et al. 1998, 


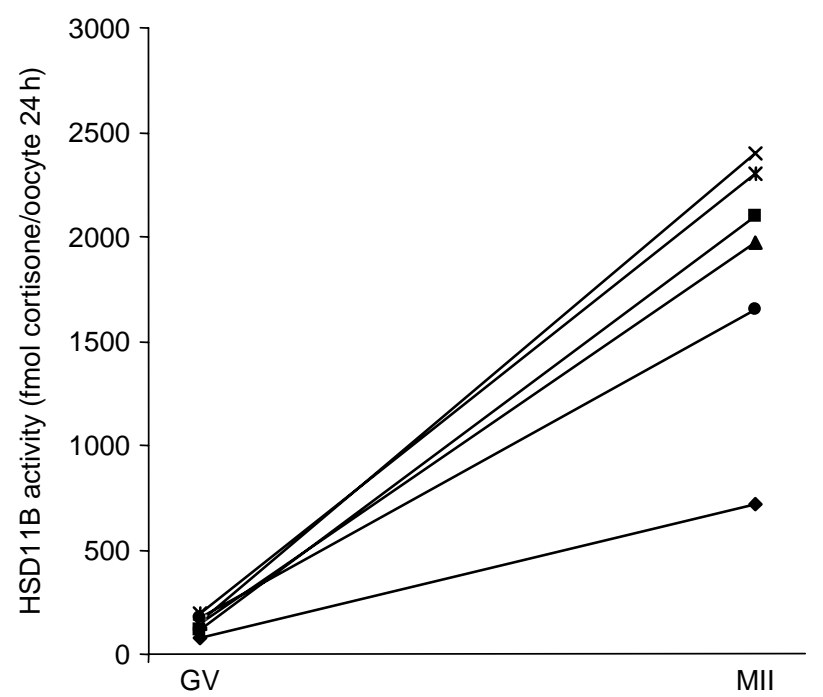

Figure 3 The net oxidation of cortisol by HSD11B differs between GV and MII stage porcine oocytes. GV stage denuded oocytes were incubated in M199 medium containing FSH (500 ng/ml) for $48 \mathrm{~h}$ and confirmed to have reached MII by extrusion of a polar body. These denuded MII oocytes were assayed for cortisol metabolism in groups of three to five per group alongside groups of five freshly collected denuded GV stage oocytes. For each of the six independent batches of MII oocytes, the mean enzyme activities are represented by different symbols, connected to the corresponding mean value for GV stage oocytes in the same enzyme assay by a diagonal line.

Smith et al. 2000), this study is the first to demonstrate that at least one HSD11B enzyme is functional in the mammalian (porcine) oocyte/COC, controlling the exposure of oocytes to physiological glucocorticoids by catalysing the conversion of cortisol to inactive cortisone. Furthermore, during the nuclear maturation of porcine oocytes, the oxidative activity of HSD11B is dramatically increased. Since glucocorticoids have been reported to inhibit the nuclear maturation of porcine oocytes, apparently by repressing the expression of the cyclin D1 component of the MPF complex (Yang et al. 1999, Chen et al. 2000), this raises the possibility that progression of porcine oocytes to the ovulatory MII stage may require an increase in the enzymatic capacity of those oocytes to inactivate cortisol.

In the present study, cortisol oxidation could be measured in completely denuded porcine oocytes, confirming that there must be an operational HSD11B enzyme (or enzymes) expressed within the oocyte itself. The finding that rates of cortisol metabolism were consistently higher in COCs than in DOs suggests that either HSD11B enzymes may also act to metabolise cortisol within the associated cumulus granulosa cells or that the presence of cumulus granulosa cells serves to stimulate HSD11B activity within the oocyte. In both COCs and DOs, the oxidation of cortisol was inhibited by both GA and CBX and while these compounds are established inhibitors of both cloned HSD11B enzymes (Monder et al. 1989, Stewart et al. 1990, (a)
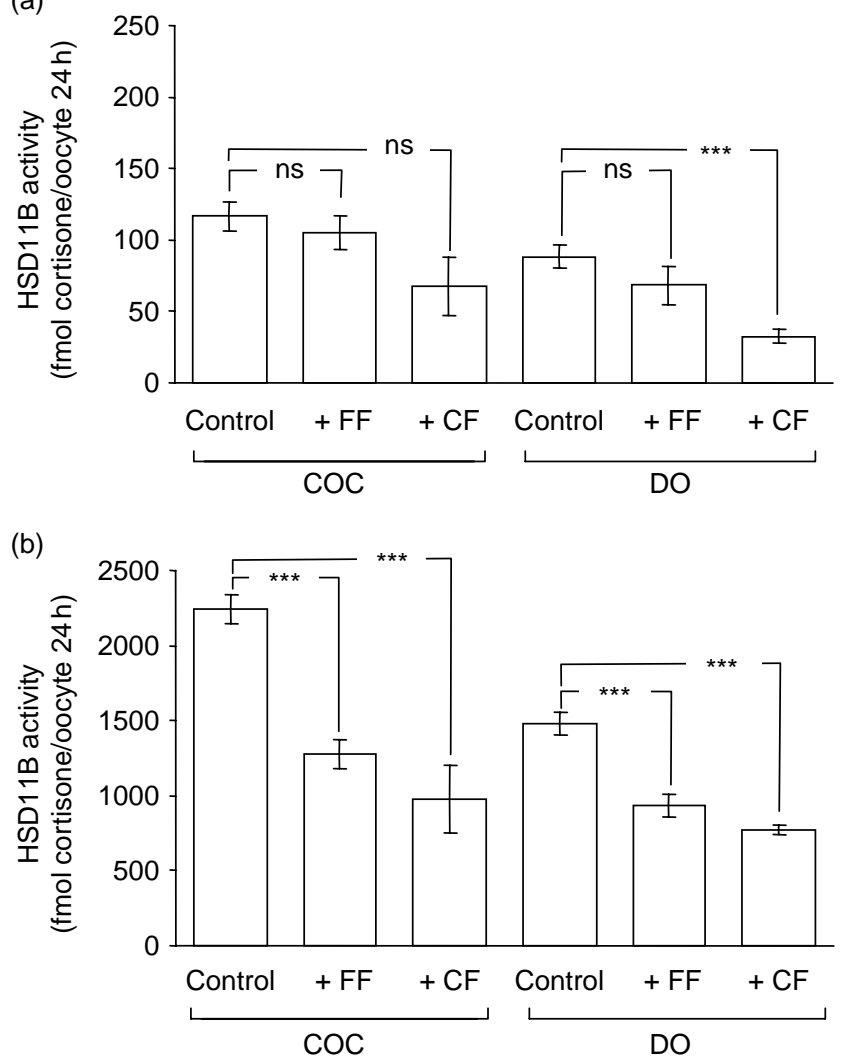

Figure 4 Follicular fluid from large antral follicles (FF) and from spontaneous ovarian cysts (CF) inhibit the on the net oxidation of cortisol by HSD11B in porcine COCs and DOs. Enzyme activities were assessed by incubating (a) COCs and denuded oocytes from compact COCs and (b) COCs and denuded oocytes from expanded COCs with $100 \mathrm{nmol} / \mathrm{l}\left[{ }^{3} \mathrm{H}\right]$-cortisol in the presence of medium alone (control), $10 \%(\mathrm{v} / \mathrm{v}) \mathrm{FF}$ or $10 \%(\mathrm{v} / \mathrm{v})$ CF. The bars represent the mean \pm S.E.M. enzyme activity in the presence of FF or CF as a percentage of that control value ( $n=5$ in each case). ${ }^{* * *} P<0.001$ versus the corresponding COCs/DOs incubated in the absence of FF or CF.

Buhler et al. 1991, Kageyama et al. 1992, Latif et al. 1992, Marandici \& Monder 1993, Ulick et al. 1993), they are also known to block gap-junctional communication (Davidson et al. 1986, Davidson \& Baumgarten 1988, Goldberg et al. 1996). Their potential effects on gap junctions in the COCs are unlikely to account for the suppression of cortisol metabolism since both GA and CBX were used a concentration of $10 \mu \mathrm{mol} / \mathrm{l}$, which is an order of magnitude lower than the concentration of CBX $(100 \mu \mathrm{mol} / \mathrm{l})$ required to block the passage of small molecules and ions between the oocyte and cumulus cells (Webb et al. 2002a, 2002b). Moreover, GA and CBX significantly inhibited cortisol metabolism in DOs where the blockade of gap junctions would be irrelevant.

In addition to testing the effects of GA and CBX, we also assessed the impact of porcine FF from large antral follicles and of porcine CF on cortisol metabolism in oocytes. Previously, we have reported that antral fluid contains compounds that can selectively inhibit the 
$\mathrm{NADP}(\mathrm{H})$-dependent activities of HSD11B1 without affecting the $\mathrm{NAD}^{+}$-dependent oxidation of cortisol by HSD11B2 in homogenates of rat kidney (Thurston et al. 2003b, Sunak et al. 2007). Levels of these endogenous ovarian inhibitors are lowest in FF from large antral follicles, but highest in CF from spontaneous ovarian cysts (Sunak et al. 2007). In the present studies, enzymatic inactivation of cortisol within porcine COCs and DOs could be inhibited by both CF (tested on the basis of its maximal content of ovarian HSD11B inhibitors) and, more importantly, by large antral FF. These findings indicate that compounds present within antral fluid of porcine ovarian follicles are capable of modulating cortisol-cortisone metabolism in porcine oocytes.

Irrespective of their nuclear maturation status, both COCs and DOs only exhibited net oxidation of cortisol to cortisone with no detectable reduction of cortisone back to cortisol. Since the 11-ketosteroid reductase activity of HSD11B1 has been reported to be labile (Lakshmi \& Monder 1985, Agarwal et al. 1995, Blum et al. 2000, Blum \& Maser 2003), we cannot categorically exclude the possibility that there is reduction of cortisone to cortisol by porcine oocytes in vivo and that, this reductase activity is lost during the isolation of the oocytes and the subsequent enzyme assays. However, the absence of any detectable 11-ketosteroid reductase activity in porcine COCs and DOs is in good agreement with our previous studies of cortisol-cortisone metabolism in mural granulosa cells recovered from porcine antral follicles at different stages of development (Sunak et al. 2007). Hence, it would appear that in the porcine ovary, the HSD11B enzyme(s) functions predominantly as an $11 \beta$-dehydrogenase enzyme to inactivate cortisol with no capacity to regenerate cortisol from circulating cortisone.

Although HSD11B1 is intrinsically bidirectional, it usually acts predominantly (if not exclusively) as a reductase to regenerate cortisol in tissues such as the liver (Seckl \& Walker 2001, Tomlinson et al. 2004, Draper \& Stewart 2005). It had been assumed that this was true of all tissues, but recent studies have established that the predominant direction of activity for HSD11B1 is sensitive to the ratio of $\mathrm{NADPH} / \mathrm{NADP}^{+}$in the lumen of the smooth endoplasmic reticulum, which in turn depends on carbohydrate metabolism by hexose-6phosphate dehydrogenase (Draper et al. 2003, Atanasov et al. 2004, Banhegyi et al. 2004, Bujalska et al. 2005, Czegle et al. 2006, McCormick et al. 2006, Odermatt et al. 2006, White et al. 2007). While it is conventionally accepted that pyruvate and glutamine (and to a lesser extent acetyl-CoA derived from non-esterified fatty acids) are the major respiratory substrates for mammalian oocytes (Downs et al. 1997, 2002, Downs \& Hudson 2000, Johnson et al. 2007, Songsasen et al. 2007), there are emerging roles for glycolytic oxidation of glucose and the pentose phosphate pathway in oocyte maturation (Downs et al. 1998, Harris et al. 2007). This could set the balance of $\mathrm{NADPH} / \mathrm{NADP}^{+}$in the mammalian oocyte such that HSD11B1 acts as a predominant $11 \beta$-dehydrogenase enzyme to inactivate glucocorticoids.

Previous studies have focused on the activities of the more conventional hydroxysteroid dehydrogenase enzymes, namely HSD11B, HSD17B, 20aHSD and $20 \beta \mathrm{HSD}$, during oocyte maturation. Immunohistochemical studies of mouse oocytes suggest that the activities of HSD3B1, HSD17B and 20ßHSD remain constant during oocyte maturation, and while the activity of $20 \alpha \mathrm{HSD}$ increases following hCG administration (either in vivo or in vitro), this occurs independently of meiotic maturation (Niimura \& Kawakami 2003). Hence, this is the first report of a quantitative association between changes in the activity of any specific HSD enzyme as oocytes mature from the GV to the MII stage. At this time, we are unable to state whether the marked increase in cortisol metabolism by HSD11B is a cause or the consequence of the progression of porcine oocytes to MII: we have yet to determine whether meiotic progression can only occur in those oocytes in which the ability of the HSD11B enzymes to inactivate cortisol has already been increased.

In the mammalian ovary, the expression and activity of HSD11B1 are sensitive to a variety of endocrine/ pararcine regulators, including LH/hCG (Tetsuka et al. 1997, 1999, Thurston et al. 2003c) and prostaglandin $E_{2}$ (Jonas et al. 2006, Chandras et al. 2007). In expanded COCs, it seems likely that the enclosed oocytes would have been subjected to the start of an $\mathrm{LH}$ surge in vivo prior to isolation which could account for their relatively high levels of cortisol oxidation. Similarly, in the IVM experiments reported herein, all COCs were exposed for $48 \mathrm{~h}$ to both $\mathrm{FSH}$ and $\mathrm{LH}$, which may have increased the expression of HSD11B1 in those oocytes that progressed to MII.

In conclusion, these studies have established that the porcine oocyte expresses at least one functional HSD11B enzyme that acts to decrease the local glucocorticoid concentration by catalysing the oxidative inactivation of cortisol to cortisone. Moreover, the rate of steroid metabolism increases markedly coincident with oocyte maturation from the GV to the MII stage, suggesting that the increase in HSD11B enzyme activity may limit the potentially adverse effects of cortisol on the nuclear maturation of porcine oocytes.

\section{Materials and Methods}

\section{Collection of oocytes, follicular and CFs}

Sow ovaries were obtained from ANG Barbers abattoir (Chelmsford, Essex, UK) and transported in a Dewar flask at room temperature. On arrival in the lab, ovaries were washed twice in $0.9 \%(\mathrm{w} / \mathrm{v})$ saline, after which antral follicles were classified as small (2-3 mm), medium (4-7 mm), large 
(8-12 mm) or cystic follicles (20-40 $\mathrm{mm}$ in diameter). Within $5 \mathrm{~h}$ of collecting the ovaries, COCs were aspirated from non-cystic antral follicles in FF using a 21.1 gauge needle. The COCs were transferred from the FF into warm M199 medium (Invitrogen) supplemented with $10 \%(\mathrm{v} / \mathrm{v})$ foetal bovine serum (FBS; Invitrogen), penicillin (100 IU/ml) and streptomycin $(0.1 \mathrm{mg} / \mathrm{ml}$; Invitrogen) and held thereafter at $39^{\circ} \mathrm{C}$. The remaining $\mathrm{FF}$ from large antral follicles and $\mathrm{CF}$ aspirated from spontaneous ovarian cysts during oocyte retrieval were each centrifuged at $250 \mathrm{~g}$ for $10 \mathrm{~min}$ at $4{ }^{\circ} \mathrm{C}$ to precipitate any contaminating granulosa cells. The acellular samples of FF and CF were then transferred into prelabelled polypropylene tubes and stored at $-20{ }^{\circ} \mathrm{C}$ for up to 3 months (over which time the levels of lipid inhibitors of HSD11B1 activity did not change on storage).

COCs were examined under a Leica MZ 12.5 dissecting microscope and classified as either compact COCs or expanded COCs, dependent on the appearance of the cumulus cells. Compact COCs contained GV stage oocytes with three or more concentric layers of tightly attached cumulus cells, whereas expanded COCs contained oocytes that had undergone GVBD and were surrounded by a diffuse arrangement of cumulus mass embedded in matrix of hyaluronic acid. In selected experiments, oocytes were denuded from either compact COCs or expanded COCs by incubating these with $1 \%(\mathrm{w} / \mathrm{v})$ hyaluronidase (Sigma) in M199 medium and vortexing gently for 2-5 min. The cumulus free DOs were then collected and washed three times in fresh pre-warmed M199 medium.

\section{IVM of oocytes}

Compact COCs, aspirated from medium diameter antral follicles, were collected and placed into an IVM medium comprising M199 medium supplemented with penicillin $(100 \mathrm{mg} / \mathrm{ml})$, streptomycin $(0.1 \mathrm{mg} / \mathrm{ml})$, epidermal growth factor $(10 \mathrm{ng} / \mathrm{ml}), \mathrm{LH}(500 \mathrm{ng} / \mathrm{ml}), \mathrm{FSH}(500 \mathrm{ng} / \mathrm{ml})$, cysteine $(0.57 \mathrm{mmol} / \mathrm{l})$, glutamine $(3 \mathrm{mmol} / \mathrm{l})$ and BSA $(4 \mathrm{mg} / \mathrm{ml})$. The COCs were then incubated at $39{ }^{\circ} \mathrm{C}$ under an atmosphere of $5 \%(\mathrm{v} / \mathrm{v}) \mathrm{CO}_{2}$ in air for $48 \mathrm{~h}$, during which time the cumulus masses underwent expansion. Following the $48 \mathrm{~h}$ IVM protocol, the expanded cumulus cells were removed by vortexing in the presence of $1 \%(\mathrm{w} / \mathrm{v})$ hyaluronidase, and the oocytes were visually assessed using a Leica MZ 12.5 dissection microscope for the presence of a PB as a marker of the nuclear maturation of the oocytes. Oocytes were then segregated according to the presence or absence of an extruded PB. Although the majority of these DOs were used directly in the radiometric conversion assay of HSD11B enzyme activities (described below), 12 oocytes that had extruded a PB within $48 \mathrm{~h}$ of IVM and ten oocytes denuded from compact COCs were each fixed in $4 \%(\mathrm{w} / \mathrm{v})$ paraformaldehyde and $0.1 \%(\mathrm{w} / \mathrm{v})$ TritonX-100. After blocking with FBS for $1 \mathrm{~h}$ at room temperature, these fixed oocytes were stained with a primary goat anti-tubulin antibody $(1 / 200 ; 1 \mathrm{~h})$ washed and incubated with a FITC-labelled anti-goat secondary antibody $(1 / 400 ; 1 \mathrm{~h}$, $\left.37^{\circ} \mathrm{C}\right)$ and with propidium iodide $(10 \mu \mathrm{g} / \mathrm{ml})$ to confirm the meiotic status of the oocytes. Fluorescence was recorded using a Olympus AX81 microscope.

\section{HSD11B activity}

Enzyme activities were measured using modifications of the radiometric conversion assays, which we have reported previously (Michael et al. 1997, Thurston et al. 2003c). In brief, COCs and DOs were incubated in $100 \mu$ volumes of serum-free M199 medium either individually (expanded COCs) or in groups of five oocytes per well (compact COCs and all DOs). Assays of enzyme activity, conducted over a 24-h incubation phase at $39^{\circ} \mathrm{C}$, were initiated by the addition of either $100 \mathrm{nmol} / \mathrm{l}\left[1,2,6,7-{ }^{3} \mathrm{H}\right]$-cortisol (specific activity= $69 \mathrm{Ci} / \mathrm{mmol}$; GE Healthcare, Buckinghamshire, UK) or $100 \mathrm{nmol} / \mathrm{l}\left[1,2-{ }^{3} \mathrm{H}\right]$-cortisone (specific activity $=40 \mathrm{Ci} / \mathrm{mmol}$; GE Healthcare). Enzyme activities were also assessed in the presence of either CBX (10 $\mu \mathrm{mol} / \mathrm{l}$; Sigma) or GA $(10 \mu \mathrm{mol} / \mathrm{l}$; Sigma), or in the presence of porcine FF from large antral follicles or porcine CF from spontaneous ovarian cysts, each tested at a final dilution of $10 \%$ by volume. In all assays, incubations were terminated after $24 \mathrm{~h}$, at which point the oocytes were visually examined to confirm no obvious degeneration had occurred, followed by extraction of the $\left[{ }^{3} \mathrm{H}\right]$-steroids into two volumes of chloroform (Merck). After resolving $\left[{ }^{3} \mathrm{H}\right]$-cortisol from $\left[{ }^{3} \mathrm{H}\right]$-cortisone by thin layer chromatography in an atmosphere of 92: 8 chloroform: 95\% $(\mathrm{v} / \mathrm{v})$ ethanol, the net fractional oxidation of $\left[{ }^{3} \mathrm{H}\right]$-cortisol to $\left[{ }^{3} \mathrm{H}\right]$-cortisone, or reduction of $\left[{ }^{3} \mathrm{H}\right]$-cortisone to $\left[{ }^{3} \mathrm{H}\right]$-cortisol, was quantified using an AR200 radiochromatogramme scanner with inline Laura Lite 3.0 software (LabLogic, Sheffield, UK).

\section{Statistical analysis}

In the first instance, all data were subjected to KolmogorovSmirnov testing to assess whether data conformed to Gaussian (Normal) distributions. Having confirmed all data to be normally distributed, mean values were then compared between groups using either unpaired $t$-tests or one-way ANOVA followed by the Bonferroni multiple comparison, as appropriate to the experimental design. All statistical tests were performed using GraphPad Prism 3.0 software (San Diego, CA, USA) and $P$ values less than 0.05 were accepted as indicating statistical significance.

\section{Declaration of interest}

The authors declare there is no conflict of interest that could be perceived as prejudicing the impartiality of the research reported.

\section{Funding}

This work was funded, in part, by a CASE PhD studentship from the Biotechnology \& Biological Sciences Research Council (BBSRC) \& Genus plc., in support of Neera Sunak.

\section{References}

Agarwal AK, Mune T, Monder C \& White PC 1995 Mutations in the putative glycosylation sites of rat $11 \beta$-hydroxysteroid dehydrogenase affect enzyme activity. Biochimica et Biophysica Acta 1248 70-74. 
Andersen CY 2003 Effect of glucocorticoids on spontaneous and folliclestimulating hormone induced oocyte maturation in mouse oocytes during culture. Journal of Steroid Biochemistry and Molecular Biology 85 423-427.

Armanini D, Karbowiak I, Krozowski Z, Funder JW \& Adam WR 1982 The mechanism of mineralocorticoid action of carbenoxolone. Endocrinology 111 1683-1686.

Atanasov AG, Nashev LG, Schweizer RA, Frick C \& Odermatt A 2004 Hexose-6-phosphate dehydrogenase determines the reaction direction of $11 \beta$-hydroxysteroid dehydrogenase type 1 as an oxoreductase. FEBS Letters 571 129-133.

Banhegyi G, Benedetti A, Fulceri R \& Senesi S 2004 Cooperativity between $11 \beta$-hydroxysteroid dehydrogenase type 1 and hexose-6-phosphate dehydrogenase in the lumen of the endoplasmic reticulum. Journal of Biological Chemistry 279 27017-27021.

Benediktsson R, Yau JLW, Low SC, Brett LP, Cooke BE, Edwards CRW \& Seckl JR $199211 \beta$-Hydroxysteroid dehydrogenase in the rat ovary: high expression in the oocyte. Journal of Endocrinology 135 53-58.

Blum A \& Maser E 2003 The critical role of the $\mathrm{N}$-terminus of $11 \beta$-hydroxysteroid dehydrogenase type 1 , as being encoded by exon 1 , for enzyme stabilization and activity. Chemico-Biological Interactions 143-144 469-480.

Blum A, Martin HJ \& Maser E 2000 Human 11ß-hydroxysteroid dehydrogenase type 1 is enzymatically active in its nonglycosylated form. Biochemical and Biophysical Research Communications 276 428-434.

Buhler H, Perschel FH \& Hierholzer K 1991 Inhibition of rat renal $11 \beta$-hydroxysteroid dehydrogenase by steroidal compounds and triterpenoids: structure/function relationship. Biochimica et Biophysica Acta 1075 206-212.

Bujalska IJ, Draper N, Michailidou Z, Tomlinson JW, White PC, Chapman KE, Walker EA \& Stewart PM 2005 Hexose-6-phosphate dehydrogenase confers oxo-reductase activity upon $11 \beta$-hydroxysteroid dehydrogenase type 1. Journal of Molecular Endocrinology 34 675-684.

Chandras C, Harris TE, Lopez Bernal A, Abayasekara DRE \& Michael AE 2007 PTGER1 and PTGER2 receptors mediate regulation of progesterone synthesis and type $111 \beta$-hydroxysteroid dehydrogenase activity by prostaglandin $\mathrm{E}_{2}$ in human granulosa-lutein cells. Journal of Endocrinology 194 595-602

Chen W-Y, Yang J-G \& Li PS 2000 Effect of dexamethasone on the expression of p34cdc2 and cyclin B1 in pig oocytes in vitro. Molecular Reproduction and Development 56 74-79.

Czegle I, Piccirella S, Senesi S, Csala M, Mandl J, Banhegyi G, Fulceri R \& Benedetti A 2006 Cooperativity between $11 \beta$-hydroxysteroid dehydrogenase type 1 and hexose- 6 -phosphate dehydrogenase is based on a common pyridine nucleotide pool in the lumen of the endoplasmic reticulum. Molecular and Cellular Endocrinology 248 24-25.

Davidson JS \& Baumgarten IM 1988 Glycyrrhetinic acid derivatives: a novel class of inhibitors of gap-junctional intercellular communication. Structure-activity relationships. Journal of Pharmacology and Experimental Therapeutics 246 1104-1107.

Davidson JS, Baumgarten IM \& Harley EH 1986 Reversible inhibition of intercellular junctional communication by glycyrrhetinic acid. Biochemical and Biophysical Research Communications 134 29-36.

Downs SM \& Hudson ED 2000 Energy substrates and the completion of spontaneous meiotic maturation. Zygote 8 339-351.

Downs SM, Houghton FD, Humpherson PG \& Leese HJ 1997 Substrate utilization and maturation of cumulus cell-enclosed mouse oocytes: evidence that pyruvate oxidation does not mediate meiotic induction. Journal of Reproduction and Fertility 110 1-10.

Downs SM, Humpherson PG \& Leese HJ 1998 Meiotic induction in cumulus cell-enclosed oocytes: involvement of the pentose phosphate pathway. Biology of Reproduction 58 1084-1094.

Downs SM, Humpherson PG \& Leese HJ 2002 Pyruvate utilization by mouse oocytes is influenced by meiotic status and the cumulus oophorus. Molecular Reproduction and Development 62 113-123.

Draper N \& Stewart PM 2005 11ß-Hydroxysteroid dehydrogenase $(11 \beta-H S D)$ and the pre-receptor regulation of corticosteroid hormone action. Journal of Endocrinology 186 251-271.

Draper N, Walker EA, Bujalska IJ, Tomlinson JW, Chalder SM, Arlt W, Lavery GG, Bedendo O, Ray DW, Laing I et al. 2003 Mutations in the genes encoding 11ß-hydroxysteroid dehydrogenase type 1 and hexose6-phosphate dehydrogenase interact to cause cortisone reductase deficiency. Nature Genetics 34 434-439.

Goldberg GS, Moreno AP, Bechberger JF, Hearn SS, Shivers RR, MacPhee DJ, Zhang YC \& Naus CC 1996 Evidence that disruption of connexon particle arrangements in gap junction plaques is associated with inhibition of gap junctional communication by a glycyrrhetinic acid derivative. Experimental Cell Research 222 48-53.

Harris SE, Adriaens I, Leese HJ, Gosden RG \& Picton HM 2007 Carbohydrate metabolism by murine ovarian follicles and oocytes grown in vitro. Reproduction 134 415-424.

Johnson MT, Freeman EA, Gardner DK \& Hunt PA 2007 Oxidative metabolism of pyruvate is required for meiotic maturation of murine oocytes in vivo. Biology of Reproduction $772-8$.

Jonas KC, Chandras C, Abayasekara DRE \& Michael AE 2006 Role for prostaglandins in the regulation of type $111 \beta$-hydroxysteroid dehydrogenase in human granulosa-lutein cells. Endocrinology 147 5865-5872.

Kageyama Y, Suzuki H \& Saruta T 1992 Glycyrrhizin induces mineralocorticoid activity through alterations in cortisol metabolism in the human kidney. Journal of Endocrinology 135 147-152.

Keay SD, Harlow CR, Wood PJ, Jenkins JM \& Cahill DJ 2002 Higher cortisol:cortisone ratios in the preovulatory follicle of completely unstimulated IVF cycles indicate oocytes with increased pregnancy potential. Human Reproduction 17 2410-2414.

Kime DE, Scott AP \& Canario AV 1992 In vitro biosynthesis of steroids, including 11-deoxycortisol and $5 \alpha$-pregnane-3 $\beta, 7 \alpha, 17,20 \beta$-tetrol, by ovaries of the goldfish Carassius auratus during the stage of oocyte final maturation. General and Comparative Endocrinology 87 375-384.

Kotelevtsev Y, SeckI JR \& Mullins JJ 1999 11 $\beta$-Hydroxysteroid dehydrogenases: key modulators of glucocorticoid action in vivo. Current Opinion in Endocrinology and Diabetes 6 191-198.

Lakshmi V \& Monder C 1985 Evidence for independent 11-oxidase and 11 -reductase activities of $11 \beta$-hydroxysteroid dehydrogenase: enzyme latency, phase transitions, and lipid requirements. Endocrinology 116 552-560.

Latif SA, Semafuko WEB \& Morris DJ 1992 Effects of carbenoxolone administered acutely to adrenalectomized rats (in vivo) on renal and hepatic handling of corticosterone by $11 \beta$-hydroxysteroid dehydrogenase. Steroids 57 494-501.

Lewicka S, von Hagens C, Hettinger U, Grunwald K, Vecsei P, Runnebaum B \& Rabe T 2003 Cortisol and cortisone in human follicular fluid and serum and the outcome of IVF treatment. Human Reproduction $\mathbf{1 8}$ 1613-1617.

Marandici A \& Monder C 1993 Inhibition by glycyrrhetinic acid of rat tissue $11 \beta$-hydroxysteroid dehydrogenase in vivo. Steroids 58 153-156.

McCormick KL, Wang X \& Mick GJ 2006 Evidence that the $11 \beta$-hydroxysteroid dehydrogenase (11 $\beta$-HSD1) is regulated by pentose pathway flux. Studies in rat adipocytes and microsomes. Journal of Biological Chemistry 281 341-347.

Michael AE, Gregory L, Walker SM, Antoniw JW, Shaw RW, Edwards CRW \& Cooke BA 1993 Ovarian 11ß-hydroxysteroid dehydrogenase: potential predictor of conception by in-vitro fertilization and embryo transfer. Lancet 342 711-712.

Michael AE, Gregory L, Piercy EC, Walker SM, Shaw RW \& Cooke BA 1995 Ovarian $11 \beta$-hydroxysteroid dehydrogenase activity is inversely related to the outcome of in vitro fertilization-embryo transfer treatment cycles. Fertility and Sterility 64 590-598.

Michael AE, Evagelatou M, Norgate DP, Clarke RJ, Antoniw JW, Stedman B, Brennan A, Welsby R, Bujalska I, Stewart PM et al. 1997 Isoforms of $11 \beta$-hydroxysteroid dehydrogenase in human granulosa-lutein cells. Molecular and Cellular Endocrinology 132 43-52.

Michael AE, Collins TD, Norgate DP, Gregory L, Wood PJ \& Cooke BA 1999 Relationship between ovarian cortisol:cortisone ratios and the clinical outcome of in vitro fertilization and embryo transfer (IVF-ET). Clinical Endocrinology 51 535-540.

Milla S, Jalabert B, Rime H, Prunet B \& Bobe J 2006 Hydration of rainbow trout oocyte during meiotic maturation and in vitro regulation by 17,20ß-dihydroxy-4-pregnen-3-one and cortisol. Journal of Experimental Biology 209 1147-1156. 
Monder C, Stewart PM, Lakshmi V, Valentino R, Burt D \& Edwards CRW 1989 Licorice inhibits corticosteroid 11 $\beta$-dehydrogenase of rat kidney and liver: in vivo and in vitro studies. Endocrinology 125 1046-1053.

Mugnier C, Gaignon JL \& Fostier A 1997 In vitro synthesis of 17,20ß,21 trihydroxy-4-pregnen-3-one by ovaries of turbot (Scophthalmus maximus L.) during oocyte maturation. General and Comparative Endocrinology 107 63-73.

Niimura S \& Kawakami SY 2003 Changes in the activities of hydroxysteroid dehydrogenases in mouse oocytes during meiotic maturation. Journal of Reproduction and Development 49 451-456.

Odermatt A, Atanasov AG, Ballazs Z, Schweizer RAS, Nashev LG, Schuster D \& Langer T 2006 Why is $11 \beta$-hydroxysteroid dehydrogenase type 1 facing the endoplasmic reticulum lumen? Molecular and Cellular Endocrinology 248 15-23.

Petrino TR, Lin YW, Netherton JC, Powell DH \& Wallace RA 1993 Steroidogenesis in Fundulus heteroclitus V: purification, characterization, and metabolism of $17 \alpha, 20 \beta$-dihydroxy-4-pregnen-3-one by intact follicles and its role in oocyte maturation. General and Comparative Endocrinology 92 1-15.

Pinter J \& Thomas P 1999 Induction of ovulation of mature oocytes by the maturation-inducing steroid 17,20 3,21 -trihydroxy-4-pregnen-3-one in the spotted sea trout. General and Comparative Endocrinology 115 200-209.

Ricketts ML, Verhaeg JM, Bujalska I, Howie AJ, Rainey WE \& Stewart PM 1998 Immunohistochemical localisation of type $111 \beta$-hydroxysteroid dehydrogenase in human tissues. Journal of Clinical Endocrinology and Metabolism 83 1325-1335.

Seckl JR \& Walker BR 2001 11 $\beta$-Hydroxysteroid dehydrogenase type 1 - a tissue - specific amplifier of glucocorticoid action. Endocrinology 142 1371-1376.

Smith MP, Mathur RS, Keay SD, Hall L, Hull MGR \& Jenkins JM 2000 Periovulatory human oocytes, cumulus cells, and ovarian leukocytes express type 1 but not type $211 \beta$-hydroxysteroid dehydrogenase RNA. Fertility and Sterility 73 825-830.

Songsasen N, Sindler RE \& Wildt DE 2007 Requirement for, and patterns of, pyruvate and glutamine metabolism in the domestic dog oocyte in vitro. Molecular Reproduction and Development 74 870-877.

Stewart PM, Wallace AM, Atherden SM, Shearing CH \& Edwards CRW 1990 Mineralcorticoid activity of carbenoxolone: contrasting effects of carbenoxolone and liquorice on $11 \beta$-hydroxysteroid dehydrogenase in man. Clinical Science 78 49-54.

Sunak N 2007 The effects of ovarian enzyme modulators on folliculogenesis and cyst development in the porcine ovary. PhD Thesis, University of London.

Sunak N, Green DF, Abeydeera LR, Thurston LM \& Michael AE 2007 Implication of cortisol and $11 \beta$-hydroxysteroid dehydrogenase enzymes in the development of porcine (Sus scrofa domestica) ovarian follicles and cysts. Reproduction 133 1149-1158.

Tetsuka M, Thomas FJ, Thomas MJ, Anderson RA, Mason JI \& Hillier SG 1997 Differential expression of messenger ribonucleic acids encoding 11 $\beta$-hydroxysteroid dehydrogenase types 1 and 2 in human granulosa cells. Journal of Clinical Endocrinology and Metabolism 82 2006-2009.
Tetsuka M, Haines LC, Milne M, Simpson GE \& Hillier SG 1999 Regulation of $11 \beta$-hydroxysteroid dehydrogenase type 1 gene expression by $\mathrm{LH}$ and interleukin- $1 \beta$ in cultured rat granulosa cells. Journal of Endocrinology 163 417-423.

Thurston LM, Norgate DP, Jonas KC, Chandras C, Kloosterboer HJ, Cooke BA \& Michael AE 2002 Ovarian modulators of 11 $\beta$-hydroxysteroid dehydrogenase (11 $\beta \mathrm{HSD})$ activity in follicular fluid from gonadotrophin-stimulated assisted conception cycles. Reproduction 124 801-812.

Thurston LM, Norgate DP, Jonas KC, Gregory L, Wood PJ, Cooke BA \& Michael AE 2003a Ovarian modulators of type $111 \beta$-hydroxysteroid dehydrogenase (11 $\beta$ HSD) activity and intra-follicular cortisol:cortisone ratios correlate with the clinical outcome of IVF. Human Reproduction 18 1603-1612.

Thurston LM, Jonas KC, Abayasekara DRE \& Michael AE 2003b Ovarian modulators of $11 \beta$-hydroxysteroid dehydrogenase (11ßHSD) activity in follicular fluid from bovine and porcine large antral follicles and spontaneous ovarian cysts. Biology of Reproduction 68 2157-2163.

Thurston LM, Chin E, Jonas KC, Bujalska IJ, Stewart PM, Abayasekara DRE \& Michael AE 2003c Expression of $11 \beta$-hydroxysteroid dehydrogenase $(11 \beta \mathrm{HSD})$ proteins in luteinizing human granulosa cells. Journal of Endocrinology 178 127-135.

Thurston LM, Abayasekara DR \& Michael AE 2007 11 $\beta$-Hydroxysteroid dehydrogenase expression and activities in bovine granulosa cells and corpora lutea implicate corticosteroids in bovine ovarian physiology. Journal of Endocrinology 193 299-310.

Tomlinson JW, Walker EA, Bujalska IJ, Draper N, Lavery GG, Cooper MS, Hewison M \& Stewart PM 2004 11 $\beta$-Hydroxysteroid dehydrogenase type 1: a tissue-specific regulator of glucocorticoid response. Endocrine Reviews 2 831-866.

Ulick S, Wang JZ, Hanukoglu A \& Rosler A 1993 The effect of carbenoxolone on the peripheral metabolism of cortisol in human patients. Journal of Laboratory and Clinical Medicine 122 673-676.

Webb RJ, Bains H, Cruttwell C \& Carroll J 2002a Gap-junctional communication in mouse cumulus-oocyte complexes: implications for the mechanism of meiotic maturation. Reproduction 123 41-52.

Webb RJ, Marshall F, Swann K \& Carroll J 2002b FSH induces a gapjunction dependent dynamic change in [CAMP] and protein kinase $A$ in mammalian oocytes. Developmental Biology 246 441-454.

White PC, Mune T \& Agarwal AK $199711 \beta$-Hydroxysteroid dehydrogenase and the syndrome of apparent mineralcorticoid excess. Endocrine Reviews 18 135-156.

White PC, Rogoff D, McMillan DR \& Lavery GG 2007 Hexose-6-phosphate dehydrogenase (H6PD) and corticosteroid metabolism. Molecular and Cellular Endocrinology 265-266 89-92.

Yang J-G, Chen W-Y \& Li PS 1999 Effects of glucocorticoids on maturation of pig oocytes and their subsequent fertilizing capacity in vitro. Biology of Reproduction 60 929-936.

Received 3 July 2008

First decision 28 July 2008

Revised manuscript received 4 September 2008

Accepted 11 September 2008 